\title{
THE INFLUENCE OF BURNISHING PARAMETERS ON THE ROUGHNESS, PLASTIC STRAIN AND SHAPE DEVIATIONS OF MARINE PUMPS CRANKSHAFT PINS IN FRESH WATER INSTALLATIONS
}

\section{WPLYW PARAMETRÓW NAGNIATANIA NA CHROPOWATOŚĆ, ODKSZTALCENIE PLASTYCZNE I ODCHYŁKI KSZTAŁTU CZOPÓW WAŁÓW POMP OKRĘTOWYCH INSTALACJI WODY MORSKIEJ}

\author{
Adam Charchalis, Robert Starosta, Wojciech Labuda \\ Gdynia Maritime University, The Faculty of Marine Engineering, \\ Morska Street 83, 81-225 Gdynia \\ e-mail: wlabuda@am.gdynia.pl,starosta@am.gdynia.pl,achar@am.gdynia.pl
}

\begin{abstract}
Angular momentum pumps are frequently applied in marine installations. Due to hard working conditions of these pumps, special corrosion wear resistant materials as well as the ones resistant to electrochemical corrosion caused by sea water are used for their production. In case of pump shafts the most frequent inefficiency is the pin wear (corrosive wear, friction wear and contact wear) in place of sealings assembly (throttle).

Burnishing as finish plastic tooling method enables obtaining machine elements of proper technological quality. Bearing in mind numerous advantages of using burnishing, it is suggested to apply it instead of machining (finish turning, grinding, polishing) to the shafts of marine angular momentum pumps.

The burnishing process was carried out by SRMD single roll burnishing tool by Yamato. The object of the paper was to determine the influence of burnishing parameters and the number of burnishing tool passes on the improvement of roughness, plastic deformation and the shape deviation of marine pumps crank pins.
\end{abstract}

Keywords: burnishing, surface layer, stainless steel, angular momentum pump

Streszczenie: W instalacjach okrętowych często wykorzystywane są pompy wirowe. Ze względu na trudne warunki ich pracy do budowy tego rodzaju pomp stosuje się materiały odporne na zużycie erozyjne oraz korozję elektrochemiczną wywołaną przez wodę morską. W przypadku wałów pomp najczęstszą niesprawnością jest zużycie czopów (korozyjne, cierne i zmęczenie stykowe) w miejscu montażu uszczelnień (dławic). Obróbka nagniataniem jako metoda wykańczająca obróbki plastycznej umożliwia uzyskanie elementów maszyn o odpowiedniej jakości technologicznej. W związku z licznymi korzyściami stosowania obróbki nagniataniem proponuje się jej zastosowanie w zamian za wykańczającą obróbkę skrawaniem (toczenie wykańczające, szlifowanie, polerowanie) do wałów okrętowych pomp krętnych. Proces nagniatania przeprowadzono nagniatakiem jednorolkowym SRMD firmy Yamato. Celem pracy było określenie wpływu parametrów nagniatania i liczby przejść nagniataka na poprawę chropowatości, odkształcenie plastyczne i odchyłek kształtu czopów wałów pomp okrętowych.

Słowa kluczowe: nagniatanie, warstwa wierzchnia, stal nierdzewna, pompy krętne. 


\section{Introduction}

Pump shafts operating in sea water conditions are subjected to wear corrosion, friction corrosion and erosion corrosion due to difficult working conditions. That is why they are made of materials resistant to corrosion. The application of an expensive material does not prevent its operating damages. The main shaft damages comprise: cracks, plastic deformations, excessive pin wear in rotor disc mounting and in throttles seal, corrosive wear, erosion wear as well as key grooves knock out. Operating experience shows excessive wear of journals which causes the decrease of their diameter and exceeding of permissible shape deviations.

The burnishing process recommended here aims at increasing the operating life of marine pump shafts for fresh water installations which should also give economic effect. Burnishing is one of the mechanical methods of finish treatment which enables achieving surface layer of exceptionally advantageous quality. The review of professional publications has demonstrated three basic aims of applying burnish treatment in the production process of machine elements $[1,2,3,4]$ : smoothness working, strengthening treatment and dimensional - surface finish machining.

Burnishing technology can be utilized in machine production plants for both single and series production. In industrial environment the burnishing process is performed on universal machine tools and on CNC machines but is rated among plastic treatment. It allows to eliminate traditional finish machining such as: super finishing, grinding, honing and polishing. Therefore the final dimensions shaping and functional properties formation by burnishing is a chipless and dustless treatment which qualifies it for ecological treatment method [5]. Burnishing process enables surface working at high dimensional precision (accuracy class 7 and 6) which makes it possible to achieve many advantages such as :

- ability to reach low roughness surface $(\mathrm{Ra}=0,32-0,04 \mu \mathrm{m})$ and high

bearing surface of roughness profile $(90 \%)$,

- surface hardness increase,

- wear resistance increase,

- increase of abrasive and mashing wear resistance,

- corrosion resistance increase,

- no abrasive grain, sharp and hard built-up edge fragments and chips on

burnished surface,

- application of burnish tools on universal lathes (the concept of one stand working),

- elimination or decrease of the time consuming operations such as: honing, lapping, grinding and polishing, 
- ability to eliminate heat treatment in specific cases,

- high process efficiency (one working transition of a tool) and production costs reduction,

- high durability of burnishing tool.

Burnishing treatment research and its influence on surface layer are being conducted in many scientific centres all over the world and their research programs deal with matters related to burnishing of cast iron [6], some heat resisting alloys, stainless steels, copper and aluminium alloys $[3,4]$, titanium and its alloys [7]as well as galvanic coatings, diffusive and padded coatings and parts produced by sintering metal powders.

Within the research an optimalization of technological parameters of burnishing was performed and the influence of the number of burnishing tool passes on the stereometric parameters of centrifugal pumps shaft pins was determined. The burnishing process is to be conducted thanks to the reduction of roughness index $\mathrm{R}_{\mathrm{a}}$. Another essential condition of technological process is to define the influence of burnishing parameters on plastic deformation and shape deviations of steel used for marine pump shafts.

\section{Samples preparation}

The rollers of $\mathrm{X} 5 \mathrm{CrNi} 1810$ stainless steel were initially machined in order to prepare the shaft pins for burnishing. The turning process was carried out on a lathe TUC 40 type by a cutting tool with removable plates WNMG 080408 WF type by Sandvik Coromant (Fig.1) During turning the following machining parameters were applied: machining speed $\mathrm{V}_{\mathrm{c}}=112 \mathrm{~m} / \mathrm{min}$, rate of feed $\mathrm{f}=0,27 \mathrm{~mm} / \mathrm{rev}$ and machining depth $\mathrm{a}_{\mathrm{p}}=0.5 \mathrm{~mm}$.

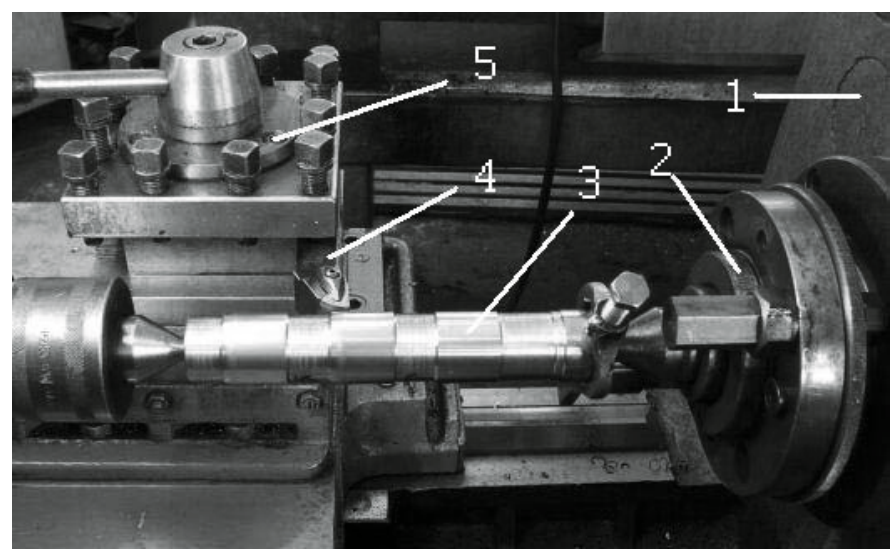

Fig.1. The view of working assembly ( machine tool, fixture, object, tool): 1-TUC 40 lathe, 2- catch plate, 3- machined object, 4- turning tool, 5 - tool post 


\section{Research methodology}

The process of burnishing was conducted by a one roll burnish SRMD type by Yamato. Shaft pins of $\phi 39 \mathrm{~mm}$ diameter were burnished. The technological process parameters applied for surface plastic treatment are shown in Table 1.

Tab. 1. Technological parameters of burnishing process

\begin{tabular}{|c|c|c|}
\hline \multicolumn{2}{|c|}{ Parameter } & Values \\
\hline Burnishing force - F & {$[\mathrm{kN}]$} & 0,$7 ; 0,9 ; 1,1$ \\
\hline Burnishing speed - $\mathrm{V}_{\mathrm{c}}$ & {$[\mathrm{m} / \mathrm{min}]$} & $35 ; 56 ; 88 ; 112$ \\
\hline Feed - f & {$[\mathrm{mm} / \mathrm{rev}]$} & $0.13 ; 0.54 ; 0.94 ; 1.2$ \\
\hline
\end{tabular}

The surface roughness was measured by HOMMEL TESTER T 1000 profile meter. The measuring length of test sample amounted to $4,8 \mathrm{~mm}$, while the sampling length was $0.08 \mathrm{~mm}$. On the basis of the results achieved, the surface $\mathrm{K}_{\mathrm{Ra}}$ roughness reduction index was define:

$$
K_{R a}=\frac{R_{a}{ }^{\prime}}{R_{a}}
$$

where:

$K_{R a} \quad$ - surface roughness reduction index

$R_{a}{ }^{\prime} \quad$ - material surface roughness,

$R_{a} \quad$ - material surface roughness after surface plastic treatment.

The $\mathrm{R}_{\mathrm{a}}$ parameter measurement was conducted in order to carry out research on the choice of burnishing parameters leading to the achievement of best roughness surface. However parameter $R_{t}$ was to define the influence of the burnishing tool on plastic deformation and consequently on the smoothness of surface roughness peaks.

Establishing the influence of the number of burnishing tool passes on the change of surface roughness reduction index $\mathrm{K}_{\mathrm{Ra}}$ will be carried out by means of experimental research based on Hartley system [8, 9,]. The research plan system utilizes three values of each quantity measured. The maximum value is marked " +1 ", the middle value is " 0 ", and the minimum value is "- $1 "$.

The results that define surface roughness underwent statistic analysis of multiple regression in order to determine their influence on the properties measured. The calculations were made by computer program Statistica 5.5. Due to different independent variables, the influence of particular 
parameters was analyzed on the basis of standardized regression index (BETA). The diameter was measured by transameter at the measuring accuracy of $0,002 \mathrm{~mm}$ in longitudinal and transversal cross-sections shown in figure 2.

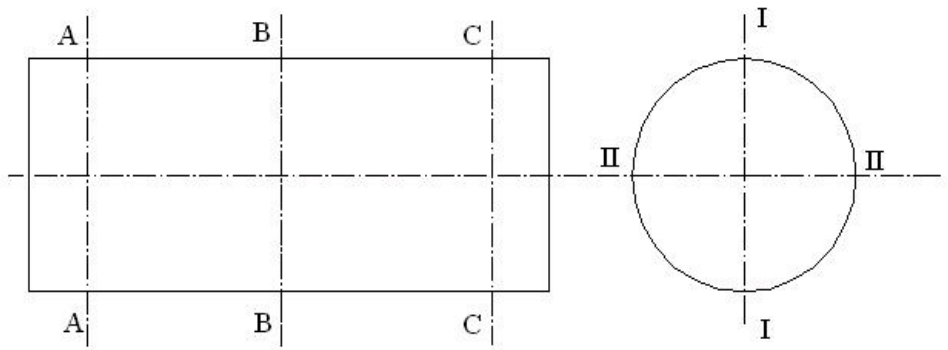

Fig. 2. Measurement of marine pumps shafts pins

Microscope examinations of pins transversal sections were done by scanning electronic microscope (SEM) Philips XL30.

\section{Research results}

It is possible to conduct a burnishing process of a corrosion resistant steel X5CrNi1810 for the purpose of decreasing the value of mean arithmetic roughness profile $R_{a}$ [10]. The technological process aiming at achieving low surface roughness should be performed with the greatest burnishing force possible and the lowest feed.

The research program and the determination of the influence of burnishing tool passes number on the change of surface roughness reduction index $\mathrm{K}_{\mathrm{Ra}}$ was presented in table 2 .

Tab. 2. The research program of the influence of chosen burnishing parameters on roughness reduction index value $\left(\mathrm{K}_{\mathrm{Ra}}\right)$

\begin{tabular}{|c|c|c|c|c|c|c|}
\hline \multirow{2}{*}{$\begin{array}{c}\text { Test } \\
\text { No. }\end{array}$} & \multicolumn{2}{|c|}{ Hartley plan system } & \multicolumn{3}{c|}{ Hartley plan completion } \\
\cline { 2 - 7 } & $\mathrm{x}_{\mathrm{F}}$ & $\mathrm{x}_{\mathrm{LP}}$ & $\mathrm{x}_{\mathrm{f}}$ & $\begin{array}{c}\text { Force } \\
\mathrm{F}[\mathrm{N}]\end{array}$ & $\begin{array}{c}\text { Number of } \\
\text { burnishing tool } \\
\text { passes LP }\end{array}$ & $\begin{array}{c}\text { Feed } \\
{[\mathrm{mm} / \mathrm{rev}]}\end{array}$ \\
\hline 1 & -1 & -1 & -1 & 720 & 1 & 0.13 \\
\hline 2 & +1 & -1 & -1 & 1140 & 1 & 0.13 \\
\hline 3 & -1 & +1 & -1 & 720 & 4 & 0.13 \\
\hline 4 & +1 & +1 & +1 & 1140 & 4 & 1.20 \\
\hline 5 & -1 & 0 & 0 & 720 & 2 & 0,54 \\
\hline 6 & +1 & 0 & 0 & 1140 & 2 & 0,54 \\
\hline 7 & 0 & -1 & 0 & 930 & 1 & 0,54 \\
\hline 8 & 0 & +1 & 0 & 930 & 4 & 0,54 \\
\hline 9 & 0 & 0 & -1 & 930 & 2 & 0,13 \\
\hline 10 & 0 & 0 & +1 & 930 & 2 & 1,20 \\
\hline 11 & 0 & 0 & 0 & 930 & 2 & 0,54 \\
\hline
\end{tabular}


According to Hartley plan for the $\mathrm{K}_{\mathrm{Ra}}$ parameter, the technological burnishing process was carried out at constant burnishing speed value $\mathrm{V}_{\mathrm{n}}=35 \mathrm{~m} / \mathrm{min}$. Other parameters used in the burnishing process are shown in table 3 .

Tab. 3. Technological parameters of burnishing process for $\mathrm{K}_{\mathrm{Ra}}$ according to Hartley

\begin{tabular}{|c|c|c|}
\hline \multicolumn{2}{|c|}{ Parameter } & Values \\
\hline Burnishing force - F & {$[\mathrm{kN}]$} & $0.7 ; 0.9 ; 1.1$ \\
\hline Feed - f & {$[\mathrm{mm} / \mathrm{rev}]$} & $0.13 ; 0.54 ; 1.2$ \\
\hline Number of passes - LP & {$[-]$} & $1 ; 2 ; 4$ \\
\hline
\end{tabular}

The influence of burnishing parameters on the surface roughness reduction index was defined by means of multiple regression analysis. Table 4 contains the values of standard regression indices (BETA), multiple regression indices (B), and the levels of importance. Constant coefficients take the following respective values: correlation coefficient $\mathrm{R}=0,67$, coefficient of determination $\mathrm{R}^{2}=0,46$ and estimation error $\mathrm{R}^{2}=0,46$.

Tab. 4. The results of $K_{R a}$ parameter statistic analysis for variables presented in table 3

\begin{tabular}{|c|c|c|c|}
\hline & BETA & B & level $\mathrm{p}$ \\
\hline Free term & & -4.87 & 0.53 \\
\hline Burnishing force - F & 0.51 & 0.01 & 0.13 \\
\hline Number of passes - LP & -0.02 & -0.08 & 0.94 \\
\hline Feed- f & -0.65 & -7.09 & 0.07 \\
\hline
\end{tabular}

Feed shows the greatest influence of the analyzed burnishing process parameters on $\mathrm{K}_{\mathrm{Ra}}$ value, which is reflected in the value of standard regression index (BETA) that equals $-0,65$. The lower the feed value applied in the burnishing process, the lower the value of mean arithmetic roughness profile $R_{a}$. The second significant parameter having an impact on the quality of the surface achieved and as a result on the parameter $\mathrm{K}_{\mathrm{Ra}}$ is the burnishing force. It can be demonstrated by the value obtained for standard regression index $(\mathrm{BETA}=0,51)$. When the value of burnishing force increases the value of parameter $R_{a}$ drops. The BETA value $=-0,02$ for the number of passes indicates its lowest influence on the value of surface roughness reduction index. The results obtained prove a considerable influence of the burnishing parameters on the optimization process of burnishing technology for parameter $K_{\mathrm{Ra}}$.

The values of importance factors (level $\mathrm{p}$ ) on independent variables of coefficient $\mathrm{K}_{\mathrm{Ra}}$ are over $5 \%$. This results from a small number of 
measurements results that underwent statistic analysis. In order to prove the influence of burnishing tool passes number on the surface layer, a test of 4 burnishing passes was conducted at optimum burnishing parameters obtained during optimization research. And so, for the technological process aiming at achieving the highest surface roughness reduction index $\mathrm{K}_{\mathrm{Ra}}-$ it is necessary to apply the highest burnishing force possible $(\mathrm{F}=1140 \mathrm{~N})$, and the lowest feed ( $\mathrm{f}=0,13 \mathrm{~mm} / \mathrm{rev}$ ). The influence of burnishing tool passes number on parameter $R_{a}$ value is shown in figure 3 . The results obtained confirm the assumed experiment plan according to Hartley showing little influence of burnishing tool passes number on the surface smoothness obtained. The first pass of burnishing tool demonstrates the greatest influence on roughness reduction index $\mathrm{K}_{\mathrm{Ra}}$. Consecutive passes also cause the reduction of $\mathrm{R}_{\mathrm{a}}$ parameter but are not as significant as in the first cycle.

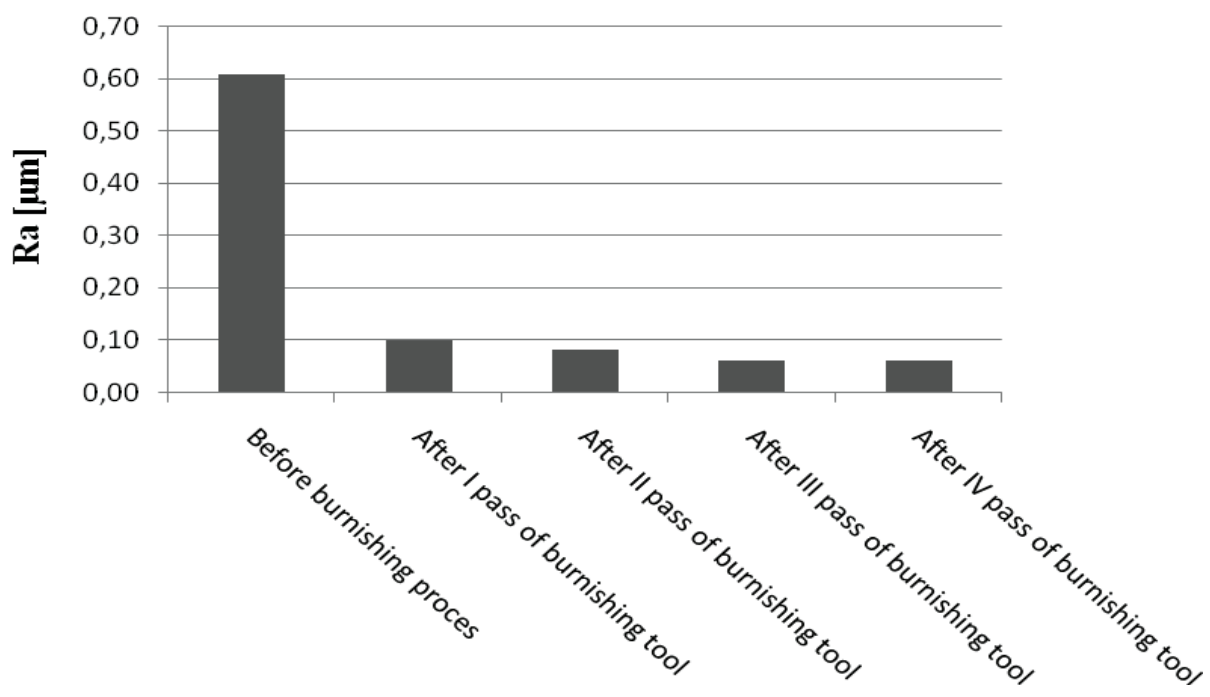

Fig. 3. The influence of burnishing tool passes number on roughness reduction index value $\left(\mathrm{K}_{\mathrm{Ra}}\right)$

The mean value obtained for parameter $\mathrm{R}_{\mathrm{t}}=5,12 \mu \mathrm{m}$ after initial machining and the mean value after burnishing $R_{t}=0,72 \mu \mathrm{m}$ prove the planishing of surface roughness peaks. The burnishing tool triggers plastic deformation of material roughness peaks causing its indentation in surface roughness valleys.

After burnishing operation the surface roughness $R_{a}$ obtained for all shaft pins was in the range of $0,06 \div 0,87 \mu \mathrm{m}$. The diameter measurements 
obtained for burnishing parameters aiming at reaching the lowest surface roughness value $\left(R_{a}=0,06 \div 0,09 \mu \mathrm{m}\right)$ are presented in table 5 .

Tab. 5. Mean diameter value for lowest $R_{a}$ value

\begin{tabular}{|c|c|c|c|c|}
\hline $\begin{array}{c}\text { Burnishing } \\
\text { speed }[\mathrm{m} / \mathrm{s}]\end{array}$ & $\begin{array}{c}\text { Feed } \\
{[\mathrm{mm} / \mathrm{rev}]}\end{array}$ & $\begin{array}{c}\text { Force } \\
{[\mathrm{N}]}\end{array}$ & $\begin{array}{c}\text { Mean diameter value } \\
\text { before burnishing }[\mathrm{mm}]\end{array}$ & $\begin{array}{c}\text { Mean diameter value } \\
\text { after burnishing }[\mathrm{mm}]\end{array}$ \\
\hline 35 & 0.13 & 1140 & 39.452 & 39.450 \\
\hline 56 & 0.13 & 1140 & 39.588 & 39.586 \\
\hline 88 & 0.13 & 1140 & 39.584 & 39.582 \\
\hline 112 & 0.13 & 1140 & 39.582 & 39.578 \\
\hline
\end{tabular}

The cross section structure of the sample examined, for which the highest surface roughness reduction index $\mathrm{K}_{\mathrm{Ra}}$ was obtained is shown in figure 4 . The metallographic research results analysis did not prove any changes in surface layer structure. The diameter micrometer changes of pins subjected to burnishing are most probably connected with low plastic strain of surface roughness peaks.

a)

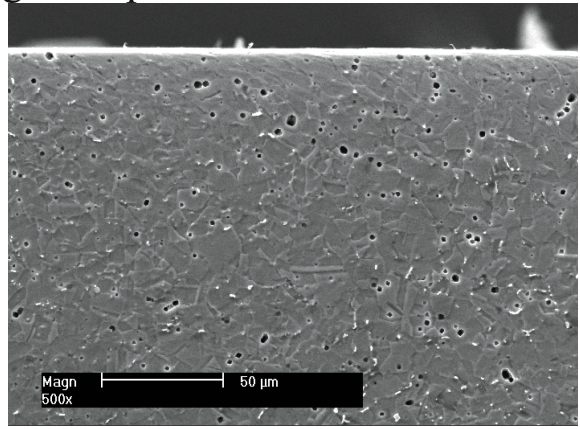

b)

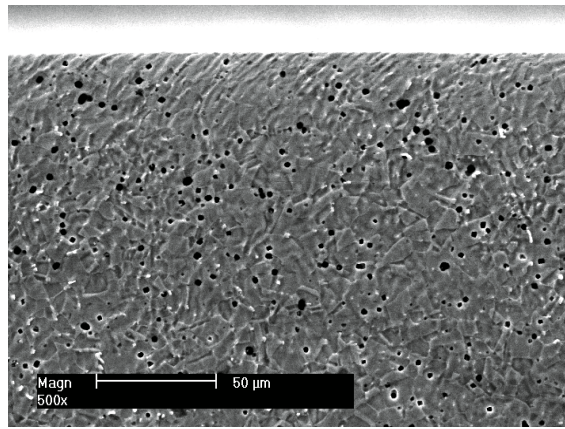

Fig. 4. View of sample surface section a) before burnishing b) after burnishing

The measurements of diameter and shape deviations obtained after lathing process are presented in table 6 whereas measurements of diameter and shape deviations after burnishing for the roughness highest surface reduction index $\mathrm{K}_{\mathrm{Ra}}$ are presented in tab. 7 .

Tab. 6. Shape deviations before burnishing

\begin{tabular}{|c|c|c|c|c|c|}
\hline \multicolumn{2}{|c|}{} & \multirow{2}{*}{$\begin{array}{c}\text { Rolling deviation } \\
\text { Diameter before burnishing [mm] } \\
\text { deviation }\end{array}$} & & \multicolumn{2}{|c|}{ Cross section } \\
\cline { 3 - 4 } & I-I & II-II & & I-I & II-II \\
\hline section & 39.584 & 39.584 & 0.000 & & \multirow{2}{*}{0.005} \\
\hline A-A & 39.588 & 39.588 & 0.000 & 0.005 \\
\hline B-B & 39.594 & 39.594 & 0.000 & & \\
\hline C-C & &
\end{tabular}


Tab.7. Shape deviations after burnishing for the highest $\mathrm{K}_{\mathrm{Ra}}$

\begin{tabular}{|c|c|c|c|c|c|}
\hline \multicolumn{2}{|c|}{} & \multirow{2}{*}{$\begin{array}{c}\text { Ovality } \\
\text { deviation }\end{array}$} & \multicolumn{2}{|c|}{ Rolling deviation } \\
\cline { 3 - 5 } & & \multicolumn{2}{|c|}{ Cross section } \\
\hline section & I-I & II-II & & I-I & II-II \\
\hline A-A & 39.582 & 39.580 & 0.000 & \multirow{2}{*}{0.005} & 0.005 \\
\hline B-B & 39.586 & 39.584 & 0.000 & & \\
\hline C-C & 39.592 & 39.590 & 0.000 & & \\
\hline
\end{tabular}

\section{Conclusions}

The application of burnishing process for corrosion resistant steel X5CrNi1810 with the use of single roll burnishing tool SRMD by Yamato makes it possible to decrease the value of mean arithmetic surface roughness profile $\mathrm{R}_{\mathrm{a}}$. The technological process aiming at reaching the lowest surface roughness value should be conducted with the highest burnishing force possible and the lowest feed. The number of burnishing tool passes does not have a considerable influence on the technological process trying to obtain the highest $\mathrm{K}_{\mathrm{Ra}}$ value. The first pass of a burnishing tool has proved to be the most effective for roughness reduction index. $K_{\mathrm{Ra}}$. The application of burnishing process for corrosion resistant steel $\mathrm{X} 5 \mathrm{CrNi} 1810$ enabled the reduction of roughness value without surface layer plastic deformations which was reflected in the results of diameter measurements and metallographic examinations. The technological process of marine pumps shaft pins production by means of burnishing does not require big allowances for finish tooling which constitutes maximum 0,006 $\mathrm{mm}$. The pins should be manufactured at their assumed accuracy class before burnishing with SRMD tool. Moreover, the burnishing process does not influence the shape deviations, which do not change considerably before and after burnishing or are in the range of measuring error.

\section{References}

[1] Przybylski, W., Technologia obróbki nagniataniem, Wydawnictwo Naukowo - Techniczne, Warszawa 1987.

[2] Przybylski,W., Wpływ stanu warstwy wierzchniej na konstytuowanej przez nagniatanie na trwałość elementów maszyn. Wybrane problemy Trybologii. PWN, Warszawa 1990.

[3] Przybylski, W., Współczesne problemy w technologii obróbki przez nagniatanie. Wydawnictwa Politechniki Gdańskiej, Gdańsk 2005. 
[4] Przybylski, W., Współczesne problemy w technologii obróbki przez nagniatanie. Tom 2, Wydawnictwa Politechniki Gdańskiej, Gdańsk 2008.

[5] Przybylski, W., Wojciechowski J., Technological and organizational aspects of cleaner manufacturing. First Cleaner Production International Conference. Rydzyna 1996.

[6] Tubielewicz, K., Technologia nagniatania żeliwnych części maszynowych, Wydawnictwa Politechniki Częstochowskiej, Monografie Nr 69, Częstochowa 2000.

[7] Golden P. J., Hutson A, Sundaram V, Arps J. H.: Effect of surface treatments on fretting fatigue of Ti-6Al-4V, International Journal of Fatigue 29 (2007) 1302-1310

[8] Górecka R., Polański Z., Metrologia warstwy wierzchniej. Wydawnictwa Naukowo - Techniczne, Warszawa, 1983

[9] Polański Z., Metodyka badań doświadczalnych. Politechnika Krakowska, Warszawa, 1984

[10]Labuda W., Starosta R., Dyl T.: Ocena wpływu parametrów nagniatania na umocnienie warstwy wierzchniej i zmianę chropowatości powierzchni stali X5CrNi1810; Journal of KONES Powertrain and Transport; Warszawa 2008; Vol. 15/ No. 3.

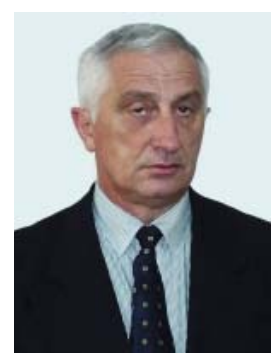

Prof. D.Sc Eng. CHARCHALIS Adam, Dean of Faculty of Marine Engineering, Director of Department of Marine Maintenance.

Professor Charchalis was a dean of Faculty of Mechanical and Electrical Engineering in Polish Naval Academy in 1994-2004. Employed as a professor Mr Charchalis works at Gdynia Maritime University since 1999. In his scientific work he deals with the problems of power plant energy of seagoing vessels, propulsion devices, ships designing, exhaust gas turbines, marine units diagnosis.Prof Charchalis created and implemented main propulsion diagnosis system of marine ships equipped with exhaust gas turbines. Prof Charchalis is an author of 3 monographs, 8 textbooks, 250 research works and thesis supervisor of 13 PhD's degrees.

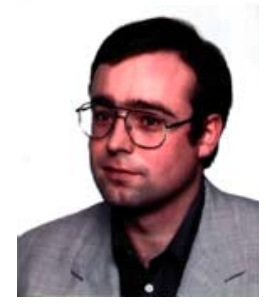

Robert Starosta, Ph.D. an assistant professor Department of Marine Maintenance of Gdynia Maritime University. In his scientific work: thermal spray coating, burnishing process.

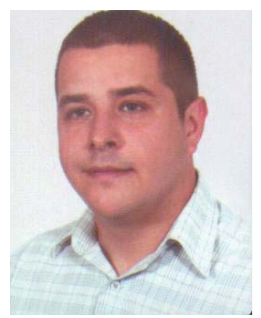

Wojciech LABUDA, M. Sc. an assistant Faculty of Marine Engineering Department of Marine Materials and Technology of Gdynia Maritime University.

In his scientific work he deal with machine tooling, plastic tooling, material processing, repair technology, metrology and measurement systems. 